Ondřej Vícha

(D) https://orcid.org/0000-0001-6639-6501

Palacky University in Olomouc, Law Faculty

Czech Republic

\title{
Czech mining law in a nutshell
}

\section{Introduction}

The purpose of this article is to briefly present the development of Czech mining law, as well as its sources and related professional literature. The author of the article discusses the common roots of Czech and Polish mining law, which date back to the Middle Ages. At present, this legal area - both in the Czech Republic and in Poland - is determined by EU and partly also by international law. However, its core is national in nature.

Mining law belongs among the traditional legal fields with a rich history in the Czech Republic. Metal-bearing ores have been mined in in the presentday territory of the Czech Republic (Bohemia, Moravia, and the Czech part of Silesia) since ancient times. But only discovery of new deposits of precious metals (especially silver) and great expansion of mining in the 13th century $\mathrm{CE}$ led to significant changes in mining and legal conditions in the Middle Ages. Originally the mining law had the nature of customary law. Over time, its content was so stabilised that it was possible and probably desirable to give it a written form, which happened in the second half of the 13th century. In addition to old customs and traditions, the first mining laws and orders began to be enforced. 


\section{Historical development of mining law in the Czech Republic}

The most well-known sources of medieval written mining law in the territory of today's Czech Republic is the so-called Jihlava mining law (Iura montium et montanorum $)^{1}$ and especially the so-called Kutná Hora mining law (Ius regale montanorum or Constitutiones iuris metallici). ${ }^{2}$ Their scope soon spread to the surrounding countries and as such became the basis and inspiration for mining law in Central Europe. As has been said, Czech and Polish mining law has common roots, because Silesia was also under influence of Jihlava and later Kutná Hora mining laws, which had been recognised here as a source of general mining law since the second half of the 13th century. ${ }^{3}$

The Kutná Hora mining law promulgated by Wenceslas the Second in the year 1300, became the basis of written mining law in the former Czech state. It is contained in four books, which for the first time enshrined in writing the principles of the mining shelf (the monarch's ownership of the extracted minerals), freedom of exploration and mining, but also the organisation of the mining administration and the judiciary. A ruler, who was considered the owner of the mined precious metals, exercised his influence through mining officials, whom he himself appointed to particular positions (e.g. perkmistr, šichtmistr or hormistr). ${ }^{4}$ The Kutná Hora mining law from 1300 had been enforceable in the territory of Czech state until 1854 when it was abolished and replaced by the General Mining Law (Imperial Law Gazette no. 146/1854). ${ }^{5}$

${ }^{1}$ See J. Pošvár̆: K počátkưm jihlavského hornictví a horního práva (On the beginnings of Jihlava's mining and mining law). „Vlastivědný sborník Vysočiny“ 1956, no. 1, pp. 33-43; P. Jánošíková: Jihlavské horni právo. (Jihlava Mining Law.) In: Naděje právní vědy. Býkov 2006. Eds. V. Knoll, V. Bednář. Plzeň 2006, pp. 253-261.

${ }^{2}$ See J. Bílek: Ius regale montanorum aneb Právo královské horníkuov (Ius regale montanorum or the Royal Law of Miners). Kutná Hora 2000; J. Majer: K 700. výroči českého Horního zákona z r. 1300 (To the 700th anniversary of the Czech Mining Act of 1300). „Uhlí, rudy, geologický průzkum“ 1999, no. 12, pp. 3-6.

${ }^{3}$ See J. Pošvár: České horní právo a jeho pronikání v Evropě v obdobi feudalismu (Czech mining law and its extension in Europe in the period of feudalism). „Acta Universitatis Brunensis, Iuridica“ 1973 , no. 8 , p. 39, including the literature referred therein.

${ }^{4}$ See R. Makarius: $Z$ dějin královské, císařské a státni báňské správy (From the history of royal, imperial and state mining administration). Ostrava 2004; O. Vícha: Vývojové tendence $v$ organizaci státní správy hornictvi a geologie (Development tendencies in the organization of state administration of mining and geology). In: Organizace státní správy - vývojové tendence. Eds. V. Sládeček, K. Frumarová, P. Melotíková. Praha 2014, pp. 198-215.

${ }^{5}$ See B. Dymeš: Horni regál a horni vlastnictví podle obecného horního zákona ze dne 23. května 1854 (Mining shelf and mining ownership according to the General Mining Act of 23 May 1854). Sbírka spisů právnických a národohospodářských. Praha-Brno 1937. For more details on the history of Czech mining law, cf. e.g. K. Effenberger: O horním právu (On the mining law). „Právní rádce“ 1996, no. 6-12; R. Makarius: Historický vývoj horního práva na 
In 1871, the foundations of the current organisation of the state mining administration were laid, when Act No. 77/1871 Coll., on the Establishment and Competence of Mining Authorities, established district officials as the firstinstance body (since 1928 district mining authorities), governor's office (with headquarters in Prague and Vienna; after the establishment of the Czechoslovak Republic, Brno became the second seat of the mining governor's office), and the Ministry of Plowing (subsequently the Ministry of Public Works) remained the third instance.

The Act No. 11/1918 Coll., on the Establishment of an Independent Czechoslovak State ${ }^{6}$ (Art. 2) brought about, inter alia, the passing of the imperial General Mining Law (Imperial Law Gazette 146/1854,), which remained in force in our territory until 1957, when it was abolished by the National Assembly of the Czechoslovak Socialist Republic and with effect from 1 January 1958 it was replaced by Act No. 41/1957 Coll., on the Utilisation of Mineral Resources (hereinafter: the Mining Act of 1957). ${ }^{7}$

The adoption of the mining regulations currently in force was preceded by a relatively lengthy preparation, which began after 1968. In the course of the preparation, more than ten mining acts were drafted. ${ }^{8}$ The Mining Act of 1957 was repealed and replaced by new mining regulations in 1988 due to the effort to increase the level of protection and exploitation of mineral resources caused by the steady increase in the consumption of basic mineral raw materials necessary for the development of the national economy while taking in account their limited character.

území českého státu (The historical development of mining law in the territory of the Czech State). „Uhlí, rudy, geologický průzkum“ 1999, no. 11, pp. 3-8.

${ }^{6}$ More on this topic e.g. V. Sládeček: K prvnímu tuctu zákonů přijatých takřka před sto lety (The first dozen laws passed almost a century ago). „Právní rádce „, 2018, no. 9.

${ }^{7}$ For more details of this act cf. E. Mráz: Horni předpisy. Praktická rukovět' usnadñujicí správně uplatňovat horní zákon a předpisy podle něho vydané (Mining regulations. Practical handle facilitating the correct application of the Mining Act and regulations issued pursuant to it). Praha 1959.

${ }^{8}$ See R. Makarius: Historický vývoj horního práva na území českého státu (The historical development of mining law in the territory of the Czech State). „Uhlí, rudy, geologický průzkum“ 1999, no. 11, p. 7. 


\section{Mining Law in force in the Czech Republic}

The core of valid Czech mining law, composed of a total of three different laws which are still in force in the Czech Republic today, ${ }^{9}$ was adopted in 1988. On 19 April 1988, Act No. 44/1988 Coll., on the Protection and Utilisation of Mineral Resources (hereinafter: the Mining Act of 1988), Act No. 61/1988 Coll., on Mining Activities, Explosives and on the State Mining Administration (hereinafter: the Act of Mining Activities), and Act No. 62/1988 Coll., on Geological Works and on the Czech Geological Office ${ }^{10}$ (hereinafter: Act on Geological Works) were published in the Czech Journal of Laws. The Mining Act of 1988 was adopted by the Federal Assembly of the Czechoslovak Socialist Republic as a federal law; the remaining laws were adopted by the national councils as laws of the republic, applicable for the individual parts of the federation. ${ }^{11}$ All these laws became effective on 1 July 1988, only shortly before the major social changes commencing in 1989. In the course of the following thirty years, a number of implementing legal regulations to these laws was adopted, including one governmental decree, ${ }^{12}$ and dozens of bylaws issued mainly by the Czech Mining Authority, but also by the Ministry of the Environment or the Ministry of Industry and Trade. ${ }^{13}$

${ }^{9}$ In 2018, we commemorated the 30th anniversary of the adoption of the basic regulations of Czech mining law. See O. Vícha: Zamyšlení nad jedním výročím horního práva (Reflections on one anniversary of mining law). „Právní rádce“ 2018, no. 12, pp. 62-67.

${ }^{10}$ The words ,and on the Czech Geological Office" were deleted from the title of the Act by the first amendment No. 543/1991 Coll. with effect from 20 December 1991.

${ }^{11}$ In the Slovak Republic the Slovak National Council adopted Act No. 51/1988 Coll. on Mining Activities, Explosives and the State Mining Administration (still in force), and Act No. 52/1988 Coll. on Geological Works and on the Slovak Geological Office [currently replaced by Act No. 569/2007 Coll. on Geological Works (Geological Act)]. For more details cf. S. Košičiarová et al.: Právo životného prostredia (Environmental law). Bratislava 2009, pp. 491-512.

${ }_{12}$ Governmental Decree No. 98/2016 Coll., on Reimbursement Rates.

${ }^{13}$ For example, Decree of the Czech Mining Authority No. 104/1988 Coll., on the Rational Use of Exclusive Deposits, Permitting and Reporting on Mining Activities and Notification of Activities Carried out by Mining, Decree of the Czech Mining Authority No. 99/1992 Coll., on the Establishment, Operation, Safeguarding and Disposal of Facilities for Waste Disposal in Underground Spaces, Decree on the Czech Mining Authority No. 172/1992 Coll., on Mining Space, Decree of the Ministry of the Environment No. 363/1992 Coll., on the Discovery of Old Mine Works and Keeping Records thereof., Decree of the Ministry of the Environment No. 364/1992 Coll., on Protected Deposit Territories, Decree of the Czech Mining Authority No. 435/1992 Coll., on Mining Surveying Documentation in Mining Activities and some Activities Carried out by Mining, Decree of the (then) Ministry for Economic Policy and Development No. 497/1992 Coll., on Recods of Stocks of Reserve Deposits, Decree of the Ministry of the Environment No. 268/2004 Coll., on Geological Documentation, Decree of the Ministry of the Environment No. 369/2004 Coll., on the Planning, Implementation and Evaluation of Geolo- 
The explanatory memorandum to the Mining Act of $1988^{14}$ states, inter alia, that "the Mining Act No. 41/1957 Coll. was issued at the beginning of the era of building socialism in the Czechoslovak Socialist Republic. Therefore, it does not contain the changes that characterise the developed form of socialism. Although in the field of mining legislation it was a pioneering act under new social conditions, mining has undergone significant changes in the following years. The extraction of minerals has increased considerably in the past period. Also, there have been some changes in opinion regarding the assessment of the importance of mineral raw materials in the development of the national economy." The purpose of the Mining Act of $1988^{15}$ was to establish the principles for the protection and economical use of mineral resources, in particular in the course of prospecting and exploration, opening, preparation and exploitation of mineral deposits, the treatment and upgrading of minerals carried out in connection with their exploitation, as well as operational safety and environmental protection during these activities. Among other things, the legal regimes for mine waters,${ }^{16}$ compensation for mining damage,${ }^{17}$ old mining works,${ }^{18}$ resolution of

gical Works, Notification of Risk Geofactors and on the Procedure for Calculating Reserves of Reserved Deposits, or Decree of the Ministry of Industry and Trade No. 29/2017 Coll., on Mining and Technical Records.

${ }^{14}$ Federal Assembly of the Czechoslovak Socialist Republic, 5th parliamentary term, print No. 49, 1987.

${ }^{15}$ Cf. R. Makarius: Horní zákon. Komentář k zákonu č. 44/1988 Sb., o ochraně a využití nerostného bohatství (horni zákon) (Mining law. Commentary on Act No. 44/1988 Coll., On the Protection and Utilization of Mineral Resources (Mining Act)). Ostrava 2013; O. Vícha: Horní zákon. Zákon o hornické činnosti, výbušninách a o státní báňské správě. Komentář (Mining law. Act on Mining Activities, Explosives and the State Mining Administration. Commentary). Praha 2017, pp. 1-468.

${ }^{16}$ More on this topic e.g. O. Vícha: Právní povaha vod z hlediska báňských předpisů (Legal nature of waters in terms of mining regulations). In: Voda v právních vztazích (Water in legal relations). Eds. I. Průchová, J. Hanák. Brno 2014, pp. 87-100.

${ }^{17}$ More on this topic e.g. O. Vícha: Náhrada důlních škod v českém právu (Compensation for mining damage in Czech law). In: Právo na životné prostredie a nástroje jeho presadzovania. (The right to the environment and tools for its enforcement). Ed. S. Košičiarová. Trnava 2016, pp. 252-262.

${ }^{18}$ More on this topic e.g. V. Lysenko: Stará důlni díla - daň vývoji lidské společnosti v Čechách (Old mining works - a tax on the development of human society in the Czech Republic). „Zpravodaj Ministerstva životního prostředí“ 1999, no. 7, pp. 5-7; O. Vícha: Odpovědnost za zajištováni a likvidaci starých a opuštěných důlnich děl (Responsibility for securing and disposing of old and abandoned mining works). „České právo životního prostředí“ 2020, no. 1(55), pp. $27-50$. 
conflicts of interest ${ }^{19}$ or special interventions in the earth's crust ${ }^{20}$ have all been introduced by the Mining Act of 1988. Regarding the last mentioned institution, it followed Act No. 24/1972 Coll., on the organisation and expansion of supervision of the state mining administration, which extended the supervision of the state mining administration to the establishment, operation and disposal of facilities for storage of gases or liquids in natural rock structures (underground gas or liquid reservoirs) including exploration and drilling work carried out for these purposes.

The Act No. 61/1988 Coll., on Mining Activities, Explosives and on the State Mining Administration, as amended ${ }^{21}$ lays down conditions for conducting mining activities themselves and activities carried out by mining (including operational safety and protection of human health during these activities), conditions for handling explosives and explosive objects, conditions for the safe operation of underground structures, and, last but not least, the organisation and scope of the authority of the state mining administration bodies. ${ }^{22}$ The State Mining Administration consists of the Czech Mining Authority and the district mining authorities. ${ }^{23}$ The Czech Mining Authority (ČBÚ) is a central state administration body based in Prague. It is headed by a chairperson, who is appointed and removed by the government. The Czech Mining Authority is subordinated to eight district mining authorities (OBÚ): District Mining Authority for the territory of the Capital City of Prague and the Central Bohemian Region, based in Prague, District Mining Authority for the Pilsen and South

${ }^{19}$ More on this topic e.g. J. Staša: Hornictví a střety ve sféře veřejného zájmu (Mining and conflicts in the public interest). „Uhlí, rudy, geologický průzkum“ 2000, no. 2, pp. 4-8; J. Czajkowski: Řešeni střetů zájmů v horním právu (Resolution of conflicts of interest in mining law). „Právní rádce“ 2006, no. 6, pp. 42-43; O. Vícha: Nature Protection and Conflict of Interests Resolution under the Mining Act. In: Sustainable development and conflicts of interests in nature protection in Czechia, Poland and Slovakia. Eds. I. Jančářová, J. Dudová. Brno 2017, pp. 197-207.

${ }^{20}$ See O. Vícha: Szczególne ingerencje $w$ skorupe ziemska z prawnego punktu widzenia (Particular cases of intrusions in the Earth's crust). In: Prawna regulacja geologii i górnictwa w Polsce, Czechach i na Slowacji (Legal regulations of geology and mining in Poland, the Czech Republic, and Slovakia). Eds. G. Dobrowolski, G. Radecki. Katowice 2014, pp. 32-46.

${ }^{21}$ Cf. R. Makarius: Zákon o hornické činnosti. Komentář k zákonu č. 61/1988 Sb., o hornické činnosti, výbušninách a o státní báňské správě v platném znění ke dni 1. 3. 2013 (Act on Mining Activities. Commentary on Act No. 61/1988 Coll., on Mining Activities, Explosives and the State Mining Administration, as amended on 1 March 2013). Ostrava 2013; O. Vícha: Horni zákon. Zákon o hornické činnosti, výbušninách a o státní báňské správě. Komentář (Mining law. Act on Mining Activities, Explosives and the State Mining Administration. Commentary). Praha 2017, pp. 471-909.

${ }^{22}$ More to this topic: O. Vícha: Správa hornictví (Mining administration). In: Správní právo - zvláštní ćást (vybrané kapitoly) (Administrative law - special part (selected chapters)).

Eds. V. Sládeček, O. Pouperová. Praha 2014, pp. 428-449.

${ }^{23}$ For more information you can see: https://www.cbusbs.cz. 
Bohemian Regions, based in Pilsen, District Mining Authority for the territory of the Karlovy Vary Region, based in Sokolov, District Mining Authority for the Ústí nad Labem Region, based in Most, District Mining Authority for the territory of the Hradec Králové and Pardubice Regions, based in Hradec Králové, District Mining Authority for the Territories of the South Moravian and Zlín Regions, based in Brno, District Mining Authority for the Moravian-Silesian and Olomouc Regions, based in Ostrava, and District Mining Authority for the Liberec and Vysočina Regions, based in Liberec. The Act on Mining Activities mentions also the concept of the environmental supervision of mining, ${ }^{24}$ without defining or specifying it.

Third basic act of the Czech mining law, the Act No. 62/1988 Coll. on Geological Works, as amended, ${ }^{25}$ provides the conditions for the planning, carrying out and evaluation of geological works, including prospecting and exploration of mineral deposits, their control and sanctions. However, the state administration in the area of geological works is not performed by the state mining administration bodies, but primarily by the Ministry of the Environment ${ }^{26}$ (whose departmental organisation is also the Czech Geological Survey ${ }^{27}$ ) and partly by regional authorities. ${ }^{28}$

Other laws extending the powers of the state mining administration bodies have been adopted more than 20 years after the adoption of the above-mentioned mining regulations. Their adoption took place as a result of the necessary transposition of relevant EU legal acts into the legal order of the Czech Republic. These acts include, in particular, Act No. 157/2009 Coll., on the management of mining waste, ${ }^{29}$ Act No. 85/2012 Coll., on the storage of carbon dioxide in

${ }^{24}$ More of this topic: O. Vícha: Ekologický dohled nad těžbou (The environmental supervision of mining). In: Kontrolni mechanismy při prosazováni ochrany životního prostředí. Eds. J. Hanák, I. Průchová. Brno 2017, pp. 183-194.

${ }^{25}$ Cf. O. Vícha: Zákon o geologických pracích. Komentár (Act on Geological works. Commentary). Praha 2020.

${ }^{26}$ For more information see: https://www.mzp.cz/cz/geologie.

27 The mission of the Czech Geological Survey, whose history dates back to 1919, is to perform the state geological service in the Czech Republic. Although the character of the institution, as well as its name, has evolved over time, its main mission and the associated unique position in society remain. The Czech Geological Survey collects and processes data on the geological composition of the state territory and transmits them to administrative bodies for political, economic and ecological decisions. For more information see: http://www.geology.cz.

${ }^{28}$ Cf. O. Vícha: Správa geologie (Geology administration). In: Správní právo - zvláštní část (vybrané kapitoly) (Administrative law - special part (selected chapters)). Eds. V. Sládeček, O. Pouperová. Praha 2014. pp. 450-464.

${ }^{29}$ More to this Act: O. Vícha: K nové právni úpravě nakládáni s těěebnimi odpady (On the new legal regulation of mining waste management). „České právo životního prostředí“ 2009, no. 2 (26), pp. 50-56; J. Kaňka, L. Šouša, V. Urbanec: Báňské předpisy XXVI. Nová právní úprava nakládánís těžebním odpadem (Mining regulations XXVI. New legislation on mining waste management). Ostrava 2010. 
natural rock structures ${ }^{30}$ Act No. 83/2013 Coll., on labeling and traceability of explosives for civil use, Act No. 259/2014 Coll., on explosives precursors, or Act No. 206/2015 Coll., on pyrotechnic products and their handling.

The preparation of the new Mining Act had already commenced by the end of 1991 (at the initiative of the former chairperson of the Czech Mining Authority), but over the past 30 years a new, modern and more user-friendly mining code has not been adopted in the Czech Republic. There exist many reasons for this, three of which, in my opinion, are crucial. Firstly, there is a division of competences in this field of public administration among three central state administration bodies (the Czech Mining Authority, the Ministry of Industry and Trade, ${ }^{31}$ and the Ministry of the Environment) and related conceptual disputes over the nature of the Mining Act. Especially in the first 10 years of the preparation of the new Mining Act, there was a dispute on the nature of this legal regulation between the Ministry of Economic Policy and Development (and subsequently the Ministry of Economy, or more precisely, the Ministry of Industry and Trade) on one side and the Ministry of the Environment on the other. ${ }^{32}$

Secondly, there is a need to reconcile different conflicting interests that occur in this sector of public administration. It is primarily the interest of state as the owner of mineral wealth in its protection and economical usage, ${ }^{33}$ the interest of private business entities (organisations $\mathrm{s}^{34}$ ) in the mining of minerals and related profits, the interest of owners and other users of real estate affected by the mining in the protection of their rights in rem and the public interest in the protection of the environment, health, or cultural heritage.

Thirdly, in the field of mining law, there is no comprehensive legal regime at the level of the European Union. EU law is based on the assumption that the area of mining and the regulation of the usage of mineral resources lie - with some exceptions - within the exclusive authority of individual Member States of the EU. Over time, however, this area has also come under the influence of EU law, especially the context of the need to meet the requirements of ensur-

${ }^{30}$ More to this Act: O. Vícha: Nová právni úprava zachytávání, přepravy a ukládání oxidu uhličitého (New legislation on carbon capture, transport and storage). „České právo životního prostředí“ 2012, no. 2 (32), pp. 88-102.

${ }^{31}$ For more information about the Ministry of Industry and Trade of the Czech Republic, see: https://www.mpo.cz.

${ }_{32}$ Cf. V. Řezníček: Problematika př́pravy nového horního kodexu a jeho úskali v současných společenských podminkách (duben 1999) (Issues of preparation of the new Mining Code and its pitfalls in the current social conditions (April 1999)). „Uhlí, rudy, geologický průzkum“ 1999, no. 12, pp. 13-18.

${ }^{33}$ Under Article 7 of the Constitution of the Czech Republic (No. 1/1993 Coll.) the state shall take care of the careful usage of natural resources and of the protection of natural resources. In accordance with Section 5 of the Mining Act of 1988 the state is the owner of mineral resources which form deposits of reserved minerals.

${ }^{34}$ Section 5a of the Mining Act, or Section 3a of Act No. 61/1988 Coll. 
ing work safety, environmental protection and health and, more recently, the need to secure the supply of critical raw materials. ${ }^{35}$ However, at the EU level no comprehensive mining code (e.g. in the form of a directive or a regulation of the European Parliament and of the Council) that would lay down unified conditions for the prospecting, exploration and exploitation of mineral resources in individual Member States of the EU has been adopted yet. ${ }^{36}$ Only some directives providing partial issues, such as the prospecting, exploration and exploitation of oil and natural gas (so-called hydrocarbons), ${ }^{37}$ management of mining waste, ${ }^{38}$ storage of carbon dioxide, ${ }^{39}$ handling explosives ${ }^{40}$ or occupational safety in mining ${ }^{41}$ have been adopted. At EU level, the legal regime for exploration and

${ }^{35}$ Cf. O. Vícha: Europeizace horního práva. (Europeanisation of mining law). „Acta Iuridica Olomoucensia“" 2017, vol. 12, no. 1, pp. 264-281.

${ }^{36}$ To the recent development of EU law in this area cf. e.g. M. Pellegrini: Fostering the Mining Potential of the European Union. „European Geologist Journal“ 2016, no. 12, pp. 10-15.

${ }^{37}$ Directive 94/22/EC of the European Parliament and of the Council of 30 May 1994 on the Conditions for Granting and Using Authorisations for the Prospection, Exploration and Production of Hydrocarbons. Cf. O. Vícha: Prospection, exploration and production of hydrocarbons under the EC-Law. In: Czech and European Environmental Law Yearbook - Volume 3. Eds. M. Damohorský. Beroun 2008, pp. 49-54.

${ }^{38}$ Directive 2006/21/EC of the European Parliament and of the Council of 15 March 2006 on the Management of Waste from the Extractive Industries and amending Directive 2004/35/ EC. Cf. O. Vícha: Nejnovější přistupy EU k nakládání s těžebními odpady (The latest EU approaches to extractive waste management). „Ekologie a právo“ 2007, no. 6, pp. 2-9.

${ }^{39}$ Directive 2009/31/EC of the European Parliament and of the Council of 23 April 2009 on the geological storage of carbon dioxide and amending Council Directive 85/337/EEC, European Parliament and Council Directives 2000/60/EC, 2001/80/EC, 2004/35/EC, 2006/12/EC, 2008/1/EC and Regulation (EC) No 1013/2006. Cf. O. Vícha: K právním nástrojům zachytávání, prepravy a ukládáni oxidu uhličitého (On legal instruments for carbon capture, transport and storage). In: Nástroje ochrany životního prostředi - role práva (Environmental protection instruments - the role of law). Ed. F. Dienstbier. Olomouc 2011, pp. 87-93.

${ }^{40}$ Directive 2014/28/EU of the European Parliament and of the Council of 26 February 2014, on the Harmonisation of the Laws of the Member States Relating to the Making Available on the Market and Supervision of Explosives for Civil Uses (recast); Commission Directive 2008/43/ EC of 4 April 2008, Setting up a System for the Identification and Traceability of Explosives for Civil Uses; Regulation (EU) 2019/1148 of the European Parliament and of the Council of 20 June 2019 on the placing on the market and use of explosives precursors, amending Regulation (EC) No 1907/2006 and repealing Regulation (EU) No 98/2013.

${ }^{41}$ For example, Directive 92/91/EEC of 3 November 1992, concerning the Minimum Requirements for Improving the Safety and Health Protection of Workers in the Mineral-Extracting Industries through Drilling, Directive 92/104/EEC of 3 December 1992, on the Minimum Requirements for Improving the Safety Health Protection of Workers in Surface and Underground Mineral-Extracting Industries or Directive 2013/30/EU of the Parliament and of the Council of 12 June 2013, on Safety of Offshore Oil and Gas Operations and Amending Directive 2004/35/ EC. Cf. O. Vícha: The newest EU law approaches to the offshore oil and gas prospection, exploration and production activities. In: Czech and European Environmental Law. A Collective Monograph. Eds. M. Damohorský, V. Stejskal.. Praha 2011, pp. 103-110. 
production of unconventional hydrocarbons (such as shale gas) takes the form of a mere recommendation from the European Commission. ${ }^{42}$

Over time the scope of mining regulations has expanded and currently it includes, besides the protection and usage of mineral resources, related areas that concern the operation of all types of mining activities or activities carried out by mining, management of mining waste or handling explosives or the management of underground facilities. ${ }^{43}$ After the change in social and political conditions in 1989 the above-mentioned regulations became repeatedly the subject of interest of the legislator, as evidenced by a number of amendments. So far, 32 acts directly amending the Mining Act (No. 44/1988 Coll.), 43 Acts amending Act No. 61/1988 Coll., on Mining Activities, Explosives and the State Mining Administration, and 18 Acts amending Act No. 62/1988 Coll. on Geological Works.

\section{The recent development of mining law in the Czech Republic}

The fundamental changes in the legal regulation of administrative punishment, which were completed with effect from 1 July 2017, also significantly affected the area of mining law. This happened in connection with the new concept of administrative punishment introduced by Act No. 250/2016 Coll., on liability for misdemeanors and proceedings against them, and Act No. 251/2016 Coll., on certain misdemeanors. Subsequently, Act No. 183/2017 Coll. amended, among other things, the provisions of the mining regulations concerning liability for misdemeanors. ${ }^{44}$

Other currently important changes have been made by two amendments to the Mining Act of 1988. The Act No. 498/2012 Coll. with effect from 15 January 2013 abolished the possibility of the expropriation of land due to mining of reserved minerals. ${ }^{45}$ The petition for annulment of this act was rejected by the

${ }^{42}$ Commission Recommendation of 22 January 2014 on minimum principles for the exploration and production of hydrocarbons (such as shale gas) using high-volume hydraulic fracturing (2014/70/EU). Cf. O. Vícha: New challenges of the EU environmental law in connection with the use of unconventional hydrocarbons. In: Environmental Law in the Czech Republic and EU - Ten Years After. Eds. M. Damohorský, V. Stejskal. Beroun 2014, pp. 57-73.

${ }^{43}$ See O. Vícha: Základy horního a energetického práva (Basics of mining and energy law). Praha 2015, p. 41.

${ }^{44}$ More on this topic: O. Vícha: Správní trestáni v horním právu (Administrative punishment in mining law). In: Správni trestání (Administrative punishment). Ed. K. Frumarová. Praha 2017, pp. 355-366.

${ }^{45}$ More on this topic: R. Makarius: Zákon č. 44/1988 Sb. přestává být horním zákonem (The Act No. 44/1988 Coll. ceases to be a mining law). „Uhlí, rudy, geologický průzkum“ 2012, no. 5 , pp. 7-9. 
Constitutional Court of the Czech Republic by its plenary resolution of 5 August 2014, file ref. Pl. ÚS 26/13. The Act No. 89/2016 Coll. with effect from 1 January 2017 introduced, inter alia, the obligation to maintain mining and technical records and it newly adjusted payments for mining areas and their management. In connection with this amendment to the Mining Act, a governmental decree No. 98/2016 Coll., on Reimbursing Rates, was adopted.

Two more amendments are currently being discussed in the Parliament of the Czech Republic. The government proposal of the Act amending the Mining Act of $1988,{ }^{46}$ among other issues, legislates for state raw material policy, specifies the regulation of mining law in the area of remediation, creation and management of reserve, reimbursement of extracted minerals and links the records of mining areas with the register of territorial identification, addresses and real estates. The government proposal of the Act amending the Act on Mining Activities (No. 61/1988 Coll. ( $^{47}$ proposes to change some provisions concerning the handling of explosives (e.g. simplification the exports of explosives or sharing the data between state mining administration and customs authorities about imports and exports of explosives) and to abolish the district mining office in Liberec due to the reduction of mining of radioactive deposits and, above all, due to the termination of mining at the Rožná deposit in the Vysočina Region.

The latest development of Czech mining regulations is influenced by several documents approved by the Government of the Czech Republic. ${ }^{48}$ The most important of these documents is the Raw Materials Policy of the Czech Republic in the field of Minerals and Their Resources approved in 2017,99 which replaced

${ }^{46}$ Government proposal of act amending Act No. 44/1988 Coll., on the Protection and Usage of Mineral Resources (Mining Act), as amended, and other related acts (Parliamentary Press No. 531/0). Cf. Dalši novela horniho zákona (Another amendment to the Mining Act). "Právní rozhledy" 2018, no. 13-14, p. II. The state of negotiations of this amendment can be monitored here: https://www.psp.cz/sqw/historie.sqw?o=8\&T=531 [accessed: 28.12.2020].

${ }^{47}$ Government proposal of act amending Act No. 61/1988 Coll., on Mining Activities, Explosives and on the State Mining Administration, as amended (Parliamentary Press No. 1003/0). The state of negotiations of this amendment can be monitored here: https://www. psp.cz/sqw/historie.sqw? $=8 \& \mathrm{~T}=1003$ [accessed: 28.12 .2020 ].

${ }^{48}$ Report on the Possibility of Solving Issues Related to the Financial Reserve to Provide Remediation and Reclamation in the Process of Smoothing out the Consequences of Mining Activities in Brown Coal Mines (Resolution of the Government of the Czech Republic of 3 May 2017, No. 333), Report on the Need to Safeguard the Economic Interests of the State in the Use of Critical EU Superstrategic Raw Materials and Certain Other Raw Materials (Resolution of the Government of the Czech Republic of 11 October 2017, No. 713) or Proposal for further action of the state in promoting the interests of the state in the protection and use of mineral deposits of the Czech Republic (Resolution of the Government of the Czech Republic of 20 July 2020, No. 757).

${ }^{49}$ Resolution of the Government of the Czech Republic of 14 June 2017, No. 441 on Raw Materials Policy of the Czech Republic in the field of Minerals and Their Resources. The text of the Raw Materials Policy of 2017 can be found here: https://www.mpo.cz/cz/stavebnic- 
the previous raw materials policy of $1999 .{ }^{50}$ It is a strategic document that expresses the objectives of the state in the area of mineral resources in accordance with the needs of the economic and social development, including environmental protection. It is based on the principle of sustainable development ${ }^{51}$ as a general overarching factor. The aim of this strategy is to ensure the raw material needs of the state, to secure stable, safe and economically beneficial access to mineral raw materials for the sustainable development of the whole society. The Czech Republic as the owner of the mineral resources has declared in this document that ,securing sufficient mineral raw materials for the domestic economy is one of its priorities, it is interested in the further refinement of knowledge about its mineral resources potential and in the consistent protection of mineral deposits, and it supports science and research, in particular in the segment of material-saving technologies, new modern or non-destructive mining methods, and a search for new types of raw materials and the new modern usage of known raw materials." Under this governmental policy a more extensive amendment to the Mining Act should be preceded by a factual expert debate and the seeking of a political consensus on selected areas (such as strengthening the role of the state in prioritising, coordinating and the targeted support for land exploration, as well as in deciding on the usage of mineral raw materials, regulation of the institution of mining area or in resolving the institution of expropriation for adequate compensation in favour of the state or its organisational units). Furthermore, in 2020 the Government of the Czech Republic adopted amendement to the Raw Materials Policy of 2017, ${ }^{52}$ outlining the efforts of the state to strengthen its role over the use of critical and supercritical raw materials and to include state components (e.g. DIAMO, state enterprise, or the Czech Geological Survey) until the effectuation of geological exploration and mining projects.

Last but not least, climate change and the move away from fossil fuels (especially coal) should be mentioned as a challenge to Czech mining law. The speed of attenuation and diversion from coal is a primary measure that can be used to meet the objective set out in transnational standards, in particular the

tvi-a-suroviny/surovinova-politika/statni-surovinova-politika-nerostne-suroviny-v-cr/nova-surovinova-politika-v-oblasti-nerostnych-surovin-a-jejich-zdroju---mpo-2017--229820/ [accessed: 28.12.2020].

${ }^{50}$ Resolution of the Government of the Czech Republic of 13 December 1999, No. 1311.

${ }^{51}$ Sustainable development of society is a development that preserves the ability of current and future generations to satisfy their basic needs while not reducing the diversity of nature and preserving natural functions of ecosystems (compare Section 6 of Act No. 17/1992 Coll. on the Environment). More on this topic: G. Dobrowolski: The role of the principle of sustainable development in the legal regulation of geology and mining. „Prawne Problemy Górnictwa i Ochrony Środowiska“ 2019, no. 1, pp. 45-56.

${ }^{52}$ Resolution of the Government of the Czech Republic of 9 March 2020, No. 183 to complement the Raw Materials Policy of the Czech Republic in the field of Minerals and Their Resources. 
Paris Agreement on Climate Change..$^{53}$ According to the recommendation of the Czech Coal Commission ${ }^{54}$ of 4 December 2020, the use of coal in power plants in the Czech Republic as well as its mining should be terminated in 2038. Addressing the complex and societal challenges of climate change, how to mitigate and adapt to them, requires the cooperation of many scientific sectors, including legal science. Mining law regulating the conditions for the use of fossil mineral resources, the combustion of which causes climate change, cannot stand aside.

\section{Conclusions}

The enormous hunger for raw materials (but also for energy and food) is putting extreme pressure on the environment, accounting for half of greenhouse gas emissions and more than $90 \%$ of biodiversity loss and water stress. Scaling up the circular economy will be vital to achieve climate neutrality by 2050 , while decoupling economic growth from resource use and keeping resource use within planetary boundaries. Access to resources and sustainability is key for the EU's resilience in relation to raw materials. Achieving resource security requires action to diversify supply from both primary and secondary sources, reduce dependencies and improve resource efficiency and circularity.

The fact that mineral deposits are not renewable, and can only be exploited at the sites of their occurrence, requires a special approach to mineral resources, rational and complex usage and its protection for the future. When preparing new regulations in the sector of mining and geology, emphasis should be placed not only on simplifying and accelerating the administrative processes leading to the protection of mineral resources and its rational and environmentally friendly usage. In addition, it will be necessary to ensure that the law in question respects the protection of property rights and the protection of the environment or its individual components (in particular soil, water, forests, nature and landscape or air) in accordance with the requirement to ensure sustainable development.

${ }^{53}$ Communication of the Ministry of Foreign Affairs of the Czech Republic on the negotiation of the Paris Agreement, adopted in Paris on 12 December 2015 (published in the Collection of International Treaties under No. 64/2017 Coll.).

${ }^{54}$ The Coal Commission is an advisory body to the Government of the Czech Republic, which was established by the Resolution of the Government of the Czech Republic of 30 July 2019, No. 565 on the Statute of the Coal Commission. 


\section{Literature}

Dalši novela horního zákona. "Právní rozhledy" 2018, no. 13-14.

Bílek J.: Ius regale montanorum aneb Právo královské horníkuov. Kutná Hora 2000.

Czajkowski J.: Řešeni střetů zájmů v horním právu. "Právní rádce" 2006, no. 6.

Dobrowolski G.: The role of the principle of sustainable development in the legal regulation of geology and mining. "Prawne Problemy Górnictwa i Ochrony Środowiska" 2019, no. 1.

Dymeš B.: Horní regál a horní vlastnictví podle obecného horního zákona ze dne 23. května 1854. Praha-Brno 1937.

Effenberger K.: O horním právu. „Právní rádce” 1996, no. 6-12.

Jánošíková P.: Jihlavské horní právo. In: Naděje právní vědy. Eds. V. Knoll, V. Bednář. Plzeň 2006.

Kaňka J., Šouša L., Urbanec V.: Báňské předpisy XXVI. Nová právní úprava nakládánís těžebnim odpadem. Ostrava 2010.

Košičiarová S. et al.: Právo životného prostredia. Bratislava 2009.

Lysenko V.: Stará důlní díla - daň vývoji lidské společnosti v Čechách. "Zpravodaj Ministerstva životního prostředí" 1999 , no. 7.

Majer J.: K 700. výročí českého Horního zákona z r. 1300. "Uhlí, rudy, geologický průzkum" 1999, no. 12.

Makarius R.: Historický vývoj horního práva na území českého státu. "Uhlí, rudy, geologický průzkum" 1999, no. 11.

Makarius R.: Z dějin královské, císařské a státni báňské správy. Ostrava 2004.

Makarius R.: Zákon č. 44/1988 Sb. přestává být horním zákonem. "Uhlí, rudy, geologický průzkum" 2012, no. 5.

Makarius R.: Horní zákon. Komentáŕ k zákonu č. 44/1988 Sb., o ochraně a využití nerostného bohatstvi (horni zákon). Ostrava 2013.

Makarius R.: Zákon o hornické činnosti. Komentár k zákonu č. 61/1988 Sb., o hornické činnosti, výbušninách a o státní báňské správě v platném znění ke dni 1. 3. 2013. Ostrava 2013.

Mráz E.: Horni předpisy. Praktická rukovět usnadñujicí správně uplatňovat horni zákon a predpisy podle něho vydané. Praha 1959.

Pellegrini M.: Fostering the Mining Potential of the European Union. "European Geologist Journal" 2016, no. 12.

Pošvář J.: K počátkům jihlavského hornictvi a horniho práva. "Vlastivědný sborník Vysočiny" 1956, no. 1.

Pošvář J.: České horni právo a jeho pronikání v Evropě v obdobi feudalismu. "Acta Universitatis Brunensis, Iuridica" 1973, no. 8.

Řezníček V.: Problematika prípravy nového horního kodexu a jeho úskalí v současných společenských podmínkách (duben 1999). "Uhlí, rudy, geologický průzkum” 1999, no. 12.

Sládeček V.: K prvnímu tuctu zákonů přijatých takřka před sto lety. "Právní rádce" 2018, no. 9.

Staša J.: Hornictví a střety ve sfére veřejného zájmu. "Uhlí, rudy, geologický průzkum" 2000, no. 2.

Vícha O.: Nejnovějši přistupy EU k nakládáni s těěebnimi odpady. "Ekologie a právo" 2007, no. 6.

Vícha O.: Prospection, exploration and production of hydrocarbons under the EC-Law. In: Czech and European Environmental Law Yearbook - Volume 3. Ed. M. Damohorský. Beroun 2008.

Vícha O.: K nové právni úpravě nakládání s těžebními odpady. "České právo životního prostředí" 2009, no. 2(26). 
Vícha O.: K právním nástrojům zachytávání, přepravy a ukládání oxidu uhličitého. In: Nástroje ochrany životního prostředi - role práva. Ed. F. Dienstbier. Olomouc 2011.

Vícha O.: The newest EU law approaches to the offshore oil and gas prospection, exploration and production activities. In: Czech and European Environmental Law. Eds. M. Damohorský, V. Stejskal. Praha 2011.

Vícha O.: Nová právní úprava zachytávání, prepravy a ukládáni oxidu uhličitého. "České právo životního prostředí” 2012, no. 2(32).

Vícha O.: Právní povaha vod z hlediska báňských predpisů. In: Voda v právních vztazích. Eds. I. Průchová, J. Hanák. Brno 2014.

Vícha O.: Vývojové tendence v organizaci státní správy hornictví a geologie. In: Organizace státni správy - vývojové tendence. Eds. V. Sládeček, K. Frumarová, P. Melotíková. Praha 2014.

Vícha O.: New challenges of the EU environmental law in connection with the use of unconventional hydrocarbons. In: Environmental Law in the Czech Republic and EU - Ten Years After. Eds. M. Damohorský, V. Stejskal. Beroun 2014.

Vícha O.: Szczególne ingerencje w skorupe ziemska z prawnego punktu widzenia. In: Prawna regulacja geologii i górnictwa w Polsce, Czechach $i$ na Slowacji. Eds. G. Dobrowolski, G. Radecki. Katowice 2014.

Vícha O.: Správa hornictví. In: Správní právo - zvláštni část. Eds. V. Sládeček, O. Pouperová. Praha 2014.

Vícha O. Správa geologie. In: Správní právo - zvláštní část (vybrané kapitoly). Eds. V. Sládeček, O. Pouperová. Praha 2014.

Vícha O. Základy horního a energetického práva. Praha 2015.

Vícha O.: Náhrada důlnich škod v českém právu. In: Právo na životné prostredie a nástroje jeho presadzovania. Ed. S. Košičiarová. Trnava 2016.

Vícha O. Europeizace horního práva. „Acta Iuridica Olomoucensia” 2017, vol. 12, no. 1.

Vícha O.: Nature Protection and Conflict of Interests Resolution under the Mining Act. In: Sustainable development and conflicts of interests in nature protection in Czechia, Poland and Slovakia. Eds. I. Jančářová, J. Dudová. Brno 2017.

Vícha O.: Ekologický dohled nad těžbou. In: Kontrolní mechanismy při prosazování ochrany životniho prostředí. Eds. J. Hanák, I. Průchová. Brno 2017.

Vícha O.: Správní trestání v horním právu In: Správní trestání. Ed. K. Frumarová. Praha 2017.

Vícha O.: Horni zákon. Zákon o hornické činnosti, výbušninách a o státni báňské správě. Komentár. Praha 2017.

Vícha O.: Zamyšlení nad jedním výročím horního práva. "Právní rádce" 2018, no. 12.

Vícha O.: Odpovédnost za zajištování a likvidaci starých a opuštěných důlních dèl. "České právo životního prostředí” 2020, no. 1(55).

Vícha O.: Zákon o geologických pracích. Komentář. Praha 2020.

Electronic sources

https://www.mzp.cz/cz/geologie

https://www.geology.cz

https://www.cbusbs.cz

https://www.mpo.cz

https://www.mpo.cz/cz/stavebnictvi-a-suroviny/surovinova-politika/statni-surovinova-politikanerostne-suroviny-v-cr/nova-surovinova-politika-v-oblasti-nerostnych-surovin-a-jejichzdroju---mpo-2017--229820/

https://www.psp.cz 
Ondřej Vícha

\title{
Czech mining law in a nutshell
}

\author{
Sum mary
}

The aim of the paper is to briefly present the development of Czech mining law, its basic sources and related literature. The author of the article recalls the common roots of Czech and Polish mining law, which date back to the Middle Ages and are currently defined by EU law.

Therefore, he mentions the relevant EU legal acts. The article examines the reasons for which the Czech Republic has the mining regulations adopted in 1988: the Mining Protection and Utilization Act (Mining Act) of April 19, 1988 (adopted by the Federal Assembly of the Czechoslovak Socialist Republic) and two acts of on April 21, 1988, on mining, explosives and the state mining administration, and on geological works (both laws were adopted by the Czech National Council).

Key words: mining, mining law, historical development, the Czech Republic

Ondřej Vícha

\section{Czeskie prawo górnicze w pigułce}

\section{Streszczenie}

Celem artykułu jest zwięzłe przedstawienie rozwoju czeskiego prawa górniczego, jego podstawowych źródeł oraz literatury pokrewnej. Autor artykułu przypomina o wspólnych korzeniach czeskiego i polskiego prawa górniczego, które sięgają średniowiecza i są obecnie określane przez prawo unijne. Dlatego też wspomina o odpowiednich aktach prawnych UE.

Artykuł analizuje przyczyny, dla których w Republice Czeskiej obowiązują przepisy górne przyjęte w 1988 roku: Ustawa o ochronie i utylizacji surowców mineralnych (Ustawa o górnictwie) z dnia 19 kwietnia 1988 r. (przyjęta przez ówczesne Zgromadzenie Federalne Czechosłowackiej Republiki Socjalistycznej) i dwie ustawy z dnia 21 kwietnia 1988 r., o górnictwie, materiałach wybuchowych i państwowej administracji górniczej oraz o robotach geologicznych (obie te ustawy zostały przyjęte przez ówczesną Czeską Radę Narodową).

Słowa klucze: górnictwo, prawo górnicze, Republika Czeska, rozwój historyczny

\section{Ондржей Виха}

\section{Чешское горное законодательство в кратком изложении}

Резюме

Цель настоящей статьи - дать краткое представление о развитии чешского горного законодательства, его основных источниках и связанной литературе. Автор статьи напоминает об общих корнях чешского и польского горного законодательства, которые восхо- 
дят к средневековью и в настоящее время регулируются законодательством ЕС. В связи с этим упоминаются соответствующие правовые акты ЕС.

В статье рассматриваются причины, по которым в Чешской Республике действует горное законодательство, принятое в 1988 году: закон об охране и использовании минеральных ресурсов (Закон о горнодобывающей промышленности) от 19 апреля 1988 года (принятый тогдашним Федеральным собранием Чехословацкой Социалистической Республики) и два закона от 21 апреля 1988 года о горнодобывающей промышленности, взрывчатых веществах, государственном управлении горной отраслью, а также геологических работах (принятые тогдашним Чешским национальным советом).

Ключевы е слова: горнодобывающая промышленность, горное законодательство, Чешская Республика, историческое развитие

\section{Ondřej Vícha}

\section{Diritto minerario Ceca in poche parole}

\section{Sommario}

Lo scopo dell'articolo è presentare brevemente lo sviluppo della legge mineraria ceca, le sue fonti di base e la letteratura correlata. L'autore dell'articolo ricorda le radici comuni della legge mineraria ceca e polacca, che risalgono al Medioevo e sono attualmente definite dal diritto dell'UE.

Pertanto, si fa riferimento agli atti giuridici dell'UE pertinenti. L'articolo esamina le ragioni per le quali la Repubblica Ceca ha adottato le norme superiori nel 1988: la legge sulla protezione e l'utilizzo delle risorse minerarie (legge sull'estrazione mineraria) del 19 aprile 1988 (adottata dall'allora Assemblea federale della Repubblica socialista cecoslovacca) e due atti di il 21 aprile 1988, la legge sull'amministrazione mineraria, gli esplosivi e l'estrazione mineraria statale e la legge sui lavori geologici (entrambe adottate dall'allora Consiglio nazionale ceco).

Parole chiave: estrazione mineraria, diritto minerario, Repubblica Ceca, sviluppo storico 